\title{
Problems of Preschool Education in the Russian Federation in the Context of the Digital Economy
}

\author{
Natalya Bobrova $^{1 *}$ Ilona Komarcheva ${ }^{1}$ \\ ${ }^{1}$ Togliatti State University, Togliatti 445020, Russian Federation \\ *Corresponding author. Email: bobrovana@mail.ru
}

\begin{abstract}
This article analyzes approaches to implementation of national projects in the area of preschool education in the context of digital economy. We show that declaration of ideas, goals and objectives at the federal level of government does not match with the methods of implementation on dreams level (at the level of the regional, local authorities). Such approaches, which have no general relationship with reality at the local level, distort the obtained result and result in ineffective spending of budget funds. Digitalization might become a solution to this by offering transparent and clear framework for funding and supporting preschool education. The private sector in the field of preschool education has significant weight in the quality of education received by preschool children. Citizens are in unequal conditions when they receive education in private educational institutions for a fixed fee. We are talking about violation of the constitutional right of citizens to free education, violation of the constitutional principle of equality.
\end{abstract}

Keywords: Pre-school education, digital economy, educational organization, education budget, equality, constitutional rights.

\section{INTRODUCTION}

Generally, the Constitution of the Russian Federation guarantees for citizens general accessibility and free of charge basis for preschool, general and secondary vocational education in state or municipal educational institutions and on enterprises [1]. The legal, organizational and economic foundations of education in the Russian Federation are enshrined in the Federal Law "On Education in the Russian Federation" dated December 29, 2012 No. 273-FZ [2] (hereinafter - FL No. 273).

The importance of education is difficult to overestimate in modern reality, especially when the digital economy and digitalization that emerged due to the spread of the information and communication technologies (ICT) is happening in every sphere of the society. The educational process begins from the moment when a child is born, and educational programs are implemented at the stage of preschool education from two months. And this process, according to constitutional norms, should be performed free of charge at the expense of the budget. But today the state sets new tasks in the field of education that meet the requirements of the time. One important requirement is digitalization of the economy and all the processes involved.

The main focus is on the process of raising extrabudgetary funds to achieve the set goals, issues of public-private interaction are being worked out. Digitalization might help to make this process more effective and transparent.
One would probably agree that national projects are the instruments by which the state must ensure high living standards, including development of education throughout Russia [3].

With regard to the above, the priority task at the current stage of development of Russia is implementation of national projects determined by the President of the Russian Federation [4]. Scientific articles were written about issues in the field of implementation of national projects related to education and science $[5,6]$.

However, they are mainly devoted to the secondary and higher levels of education and only few of them touch the issue of the very initial level, the basis of general education - preschool. This issue will be discussed in this article.

\section{STATE POLICY AND EDUCATIONAL PROGRAMS}

Federal Law No. 273 sets the basic principles of the state policy in the field of education, general rules for functioning of the education system and implementation of educational activities, determines legal status of participants in relations in the field of education. In accordance with federal educational standards, the Law sets requirements for the quality of education, while not setting restrictions on the organizational and legal form of educational organization.

The only restrictions are related to the fact that any organization that implements educational programs must have the license for such activities. The license is 
evidence that a legal entity has resources that allow it to engage in educational activities at the high-quality level.

At the broadened meeting of the Presidium of the State Council, together with the authorities of the constituent entities of the Russian Federation, the President of the Russian Federation, among other instructions, stated the need to prepare proposals for the active implementation and development of the network form for implementation of educational programs, providing for legal and financial mechanisms for allocation of resources to all organizations of various organizational and legal forms and forms of ownership in the implementation of educational programs in the network form [7].

That is, the President points out the need to implement national projects in the field of education not only by educational organizations that are state and/or municipal, but also organizations created in other organizational and legal forms that allow developing the education system and creating healthy competitive environment in the field of education.

In this regard, the Ministry of Education of Russia determines the main goals of its activities:

- The quality of education, characterized by ensuring the global competitiveness of Russian education, entry of the Russian Federation into the top 10 countries in the world in terms of the quality of general education;

- Accessibility of education, characterized by provision of preschool education for children aged under 3;

- Upbringing of a harmoniously developed and socially responsible personality on the basis of spiritual and moral values of the peoples of the Russian Federation, historical and nationalcultural traditions, characterized by increase in the coverage of children aged 5 to 18 with additional education programs [8].

And in this we see the brightly colored goal of developing the education competitiveness in Russia. As we see it, it is impossible to achieve the established goal, having in the arsenal only a limited number of educational organizations belonging to the state and/or local governments.

It is necessary to develop other sectors of education - in organizations of the different legal form, for example, organizations related to the non-profit sector.

\section{COMPETITION AND IMPLEMENTA- TION OF PROGRAMS}

In the field of education, competition should be considered not from the standpoint of antimonopoly regulation, but as a social phenomenon, as rivalry between educational organizations in their efforts to achieve legislatively established indicators in the educational, social, humanitarian and educational spheres, as rivalry between educational programs, scientific schools and other structural elements of the educational process.

One of the most important instruments of competition among educational organizations of preschool education is the qualitative composition of teachers and material and technical environment.

Budget of educational activities is financed based on the number of students in a preschool organization without taking into account the competitive characteristics of the organization. In the conditions of such equal approach to budget financing, educational organizations can hardly compete in the implementation of the main educational program. In this regard, in order to maintain the decent level of remuneration for highly qualified teachers, the organization should seek additional nonbudgetary sources of income.

And here we see the additional financial burden on parents as the main source of extra-budgetary funds. However, on the other hand, the additional income of the organization is associated with development of the field of additional education, which in its turn is also the key indicator of the effectiveness of the national project "Education", according to which at least $85 \%$ of children aged 5 to 18 should be covered by additional educational programs. And budget funds are also provided for these purposes.

However, calculation of such targeted funds is not made for all educational organizations, but only for municipal and/or state ones. Although one should not overlook the fact that other educational organizations are very successful in solving the problem of the national project without state funds.

Therefore, the process of competition in the field of education is reduced to the volume of budgetary allocations for municipal and state educational organizations and the opportunity to show achievements and scientific developments of private educational organizations that do not receive adequate budgetary funds, but offer high results achieved at the expense of investors, funds of pupils' parents in violation of their constitutional rights to free preschool education. 


\section{LEGAL CONFLICTS AND IMPLE- MENTATION}

It should be noted that the national project itself as the management tool in a broad sense is considered by us as a method, a way to achieve, implement the plan. In a more specific formulation, this is the set of interrelated activities aimed at achieving, in a certain period of time and with established budget, the tasks set with unambiguously defined goals.

The project is focused on the certain quality of the planned result, since it is used as the way to meet consumer expectations and is created for the specific need [9]. Taking into account the above specifics, we add that the tool in question also requires special organizational support. To implement the principles of team management, specific organizational conditions must be formed, including equal conditions, proclaimed at the federal level, but in fact reduced to formal actions.

For example, Article 8 of the Federal Law No. 273 establishes the powers of the state authorities of the constituent entities of the Russian Federation, namely, the state authorities of the constituent entities of the Russian Federation have the right to provide state support in the field of additional education for children in municipal and private educational organizations.

This right of the constituent entity of the Russian Federation is implemented through adoption of regulations of the constituent entity itself, in which, as a rule, due to the limited budget of the region, support measures are necessarily indicated as regulatory financing only for municipal and/or state educational organizations. Private educational organizations are deprived of such support, despite the rule of law.

The same situation is developing at the local government level (Article 9 of the Federal Law No. 273).

Therefore, in bureaucratic structures with established internal hierarchy (such as the state apparatus), project teams' creation is fraught with significant difficulties. In these structures, project teams are formed nominally, and the project management procedure itself is determined by the current system for the implementation of powers while maintaining the existing hierarchy of decisions making and decisions implementation.

For example, the main indicators for the implementation of the state program of Samara region "Development of education and increasing the effectiveness of the implementation of youth policy in the Samara region" for 2015 - 2024" [10] are indicators of state and municipal educational organizations (share of teachers receiving monthly payments; the ratio of average monthly salary of teaching staff; proportion of the actu- al number of children receiving preschool education in municipal organizations, etc.).

Each of the target indicators for the performance of the state program is supported by a certain expenditure item of the budget. However, due to a priori imposed restrictions (participation of only municipal and/or state educational organizations); other educational organizations are deprived of the opportunity to participate in this support from the state. The similar example can be found in the metropolitan area.

Decree of the Moscow Government dated 27.09.2011 No. 450-PP (as amended on 04.06.2019) "On the approval of the State program of the city of Moscow" Development of education in the city of Moscow ("Capital education")" [11] as the final results of the implementation of the State program in full volume is indicated by such indicator as "the share of children of Moscow residents aged 3-7 who receive preschool education services in state educational organizations of Moscow city, implementing educational programs of preschool education, among the number of children whose parents - residents of Moscow city have expressed the desire to receive preschool education. Planned value - $100 \% "$.

At the same time, the program specification itself defines, in particular, the following tasks:

- Comprehensive development of the network of educational organizations and educational infrastructure to ensure availability of general and additional education, regardless of the territory of residence and the state of health of pupils;

- Maximum satisfaction of the demands of Moscow residents for educational services.

\section{OUTCOMES AND CONCLUSIONS}

Therefore, it is obvious that with the existing national priorities in the development of education and the instructions given by the President of the Russian Federation on the development of healthy competition and other forms of implementation of educational programs, at the local level, these goals turn into the banal formalism that does not allow the non-state sector in the field of education to develop on equal terms.

In other words, all educational organizations that are not state and/or municipal, do not have access to budget funding that guarantees citizen's education in the organization that, in the opinion of the citizen, would most satisfy the needs of the child and his/her parents, since there is issue with financing. 
In the state and/or municipal educational organizations of preschool education, parental fees are low, since parents/legal representatives pay only for child minding and care services, and the educational process is financed by the state.

And in the private sector, which is limited in receiving budgetary funds for educational activities, the parent must pay for both child minding and care services and education itself, which in general violates the rights of the organization itself and the constitutional rights of a citizen to receive free education.

In our opinion, if a private educational organization has official license for the right to conduct activities in the field of education, then this in itself is recognition by the state of the ability and right to implement educational programs on equal basis with state organizations - from the educational organization, and, accordingly, to receive the required level of education in organizations at the request of the citizen - by the citizen himself/herself. The situations with national projects in other regions are similar.

Therefore, we believe that distortion of the indicators for calculating the results of national project activities, as well as the problems of the national projects implementation are associated not with the lack of money from the state, but with existing problems: first, in the field of legal regulation of national projects; secondly, with the national project management system [12], as well as the formal attitude of regional authorities and local governments to the principles of national projects and development vectors set at the federal level.

\section{REFERENCES}

[1] "The Constitution of the Russian Federation" (adopted by the nation-wide vote on 12.12.1993 with amendments approved during the nation-wide vote on 01.07.2020) The official text of the Constitution of the Russian Federation as amended on 03.14.2020 was published on the Official Internet portal of legal information http://www.pravo.gov.ru Accessed on $4 \mathrm{Jul}$ 2020 .

[2] The Federal Law dated December 29, 2012 No. 273-FZ (as amended on December 8, 2020) "On Education in the Russian Federation" (as amended and supplemented) // Official Internet Portal of Legal Information http://www.pravo.gov.ru, 28.12.2019, "Collected Legislation of the Russian Federation", 30.12.2019, No. 52 (Part I), Art. 7796, "Rossiyskaya Gazeta", No. 296, 31.12.2019.

[3] Meeting of the Presidium of the Council under the President of the Russian Federation for Strategic De- velopment and National Projects on February 28, 2020 // Official website of the Government of the Russian Federation. http://government.ru/news/39044/ Accessed on 14 Dec 2020

[4] The Decree of the President of the Russian Federation dated May 7, 2018 No. 204 (as amended on 07.19.2018) "On national goals and strategic objectives of the development of the Russian Federation for the period until 2024", Collected Legislation of the Russian Federation. 2018. No. 20. Art. 2817.

[5] N. Bobrova, V. Sidorov, Leading Provisions of the Digitalization, Law, Science. Series: Advances in Social Science, Education and Humanities Research, 441, in: Proceedings of the $6^{\text {th }}$ International Conference on Social, economic, and academic leadership (ICSEAL-62019) Atlantis Press, Paris, 2020, pp. 317-222. DOI: https://doi.org/10.2991/assehr.k.200526.046

[6] N. Bobrova, Devaluation of legal education: general theoretical analysis, Education and Law 8 (2018) 179181.

[7] "The list of instructions following the broadened meeting of the Presidium of the State Council" (approved by the President of the Russian Federation on December 18, 2018 No. Pr-2426GS) http://www.kremlin.ru/ as of 28.02.2019 Accessed on 5 Jan 2021

[8] "Plan of activities of the Russian Ministry of Education for the period from 2019 to 2024" (approved on 29.01.2019 No. OV-2 /02vn) Accessed on 11 Jan 2021

[9] E. Korneeva, The effectiveness of managerial work in the field of education, Economics and Management: New Challenges and Prospects 1 (2010) 146-147.

[10] The Decree of the Government of Samara Region dated 21.01.2015 No. 6 (as amended on 22.12.2020) "On the approval of the state program of Samara Region" Development of education and increasing the effectiveness of the implementation of youth policy in Samara Region" for 2015 - 2024" //Volzhskaya Kommuna, No. 16 (29215), 27.01.2015.

http://www.pravo.gov.ru Accessed on 10 Dec 2020

[11] "Bulletin of the Mayor and the Government of Moscow", No. 65, 24.11.2011. Changes introduced by the Moscow Government Decree 04.06.2019 No. 627PP.

[12] T. Vershilo, Implementation of the national projects: legal problems and ways to solve them, Financial Law 8 (2020) 21-23. DOI: https://doi.org/10.18572/1813-1220-2020-8-21-23 